\title{
Effects of Different Priming Treatments on Seed Germination Properties, Yield Components and Grain Yield of Lentil (Lens culinaris Medik.)
}

\author{
Faruk TOKLU
}

\author{
Cukurova University, Agricultural Faculty, Field CropsDepartment, 01330 Adana, Turkey;fapet@cu.edu.tr
}

\begin{abstract}
An experiment was conducted under laboratory and field conditions in order to evaluate the effects of different priming treatments, specifically $\mathrm{KNO}_{3}(1 \%), \mathrm{KCl}(2 \%), \mathrm{KH}_{2} \mathrm{PO}_{4}(1 \%), \mathrm{ZnSO}_{4}(0.05 \%)$, PEG-6000 (20\%), IBA (100 ppm), Mannitol (4\%), $\mathrm{GA}_{3}(100 \mathrm{ppm})$ and distilled water, on seed germination properties and several agro-morphological plant characteristics of red lentil. Seeds not primed were used as a control. GA 3 treatment increased shoot length. The control (non-primed seeds) treatment resulted in increased seedling root number and length. Distilled water, $\mathrm{ZnSO}_{4}$ and control treatments increased germination rate and percentage. In the pot experiments, $\mathrm{GA}_{3}$ treatment increased plant height and seedling emergence rate, whereas $\mathrm{KCl}$ treatment improved the number of nodules, as well as root and shoot dry weight when compared to the control. $\mathrm{ZnSO}_{4}$ treatment increased yield components and grain yield in field conditions. The results of this study showed that $\mathrm{ZnSO}_{4}$, $\mathrm{GA}_{3}$ and PEG-6000 seed priming treatments may be useful tools due to their positive effects on germination rate, germination percentage, yield component and grain yield of lentil.
\end{abstract}

Keywords: germination, grain yield, lentil, seed priming

\section{Introduction}

Lentil (Lens culinaris Medik.) is a diploid $(2 \mathrm{n}=2 \mathrm{x}=14)$, selfpollinated (autogam) and annual species of grain legume. Lentil is one of the most ancient crops, first cultivated 7,000-8,000 years ago (Cubero, 1981; Lev-Yadun et al., 2000). Lentil is an important source of protein, minerals and vitamins in the human diet (Karakoy et al., 2012; Muehlbauer et al., 2006; Solanki et al., 1999). Lentil is cultivated as a rainfed crop on 4.3 million hectares, which yields 4.9 million tons; in Turkey, it is grown on 281 thousand hectares and yields 417 thousand tons (FAO, 2013). Biotic and abiotic stress conditions, such as drought, cold, insufficient rainfall, salt stress and disease, are the most common restrictive conditions in lentil-growing areas and negatively affect lentil production. Germination and seedling emergence stages are critical for crop production; rapid and uniform field emergence is essential to achieve high yield and uniform plant stands, resulted in early maturity and reduced disease attack (Ali et al., 2005; Cheng and Bradford, 1999; Subedi and Ma, 2005). Finding ways to overcome environmental stresses, such as inadequate moisture during seed germination, is important for an economic crop production (Ashrafand Rauf, 2001).

Much research has been conducted involving germination and growth within uniform seed plantings. Pre-sowing seed treatments (seed priming) before germination and metabolic activity in grass seed have been reported to have a positive effect on seedling growth (Bradford, 1986). Seed priming treatments resulted in positive effects on many field crops, such as wheat, sugar beet, maize, soybean and sunflower (Parera and Cantliffe, 1994; Saglam et al., 2010). Seed priming treatment activates some metabolic activity without actual germination. For priming treatment, seeds are immersed in a solution with high osmotic potential. In this case, sufficient water uptake for seed germination was prevented, thus suspending the seeds in the lag phase (Ashraf and Foolad, 2005; Taylor et al., 1998). Seed priming treatments are widely used to reduce the time between the planting date and the seedling formation period, and to provide uniform plant growth (Parera and Cantliffe, 1994). Water deficit pose an increasing problem worldwide, especially in arid and semi-arid zones where the water intake period for seed germination is limited. Therefore, seedling stand establishment is dependent upon rapid and uniform germination (Fischer and Turner, 1978; Yordanov et al., 2000).

The most common seed priming treatments used to increase seed germination and synchronization are osmopriming (immersing the seeds in solutions with osmotic potential), halopriming (placing the seeds a salt solution), hydropriming (placing the seeds in water), matripriming (placing the seeds between saturated jute mat layers) and hardening (alternately soaking and drying the seeds) (Basra et al., 2003; Khan, 1992; McDonald, 2000). Ghassemi-Golezani et al. (2008) reported that hydropriming treatments increased the weight of the seedling root, the germination rate, as well as shoot, root and seedling dry weight. $\mathrm{KNO}_{3}$ and PEG treatments increased germination percentages when compared to the control. Saglam 
154

et al. (2010) reported priming treatments decreased the effects of water stress, and Ghassemi-Golezani et al. (2013) observed that hydropriming treatments to lentil seeds increased the plant height, number of pods and number of seeds per plant, the 1,000 grain weight, the bilogical yield, the grain yield and the harvest index when compared to the control.

The aim of this study was to research the effects of osmo- and hydro-priming treatments to lentil seeds, to analyse the influence of sucha treatment over seed germination properties and some plant characteristics, yield components and grain yield in an experiment conducted with field conditions.

\section{Materials and methods}

\section{Seed materials and priming treatments}

This study was conducted at the Vocational School of Kozan, Çukurova University. Seeds of red lentil cultivar 'Firat 87 ' were used. Newly harvested seeds were kindly obtained from Dicle University, Agricultural Faculty, Field Crops Department. Solutions of $\mathrm{KNO}_{3}(1 \%), \mathrm{KCl}(2 \%), \mathrm{KH}_{2} \mathrm{PO}_{4}(1 \%), \mathrm{ZnSO}_{4}$ (0.05\%), PEG-6000 (20\%), IBA (100 ppm), Mannitol (4\%), $\mathrm{GA}_{3}(100 \mathrm{ppm})$ and distilled water were used for priming treatments (Ghassemi-Golezani et al., 2008; Giri and Schillinger, 2003; Michel and Kaufmann, 1973; Yari et al., 2011). All priming media were prepared in distilled water. Unprimed seeds were used as a control. The seeds were divided into ten subsamples of $95 \mathrm{~g}$ each, and one sub-sample was used as the control (unprimed). The nine other sub-samples were used for priming treatments. Lentil seeds were primed seperately in 1,000 mL solutions of each respective priming agent at $20{ }^{\circ} \mathrm{C}$ for $12 \mathrm{~h}$ under dark conditions in an incubator (Ghassemi-Golezani et al., 2008). All primed seeds were then removed from the priming media and the surface sterilized (including control seeds) with $2 \%$ sodium hypochlorite $(\mathrm{NaOH})$. After the surface sterilization, seeds were washed with distilled water and dried on paper towels at room temperature, under ventilated conditions, until they regained their original moisture content (GhassemiGolezani et al., 2008).

These primed seeds were used for germination tests in laboratory, pot and field experiments. Electrical conductivity, $\mathrm{pH}$ and seed weight gain (\%) after priming treatments were analysed with specific methodology.

\section{Germination tests}

Germination tests were carried out according to standard protocols established by the International Seed Testing Association (ISTA). The experimental units were arranged in a completely randomized design with four replications. Twentyfive seeds from each of the priming treatments were placed on the moistened filter papers in petri dishes and germinated in an incubator at $10 \pm 1^{\circ} \mathrm{C}$. Germination of seeds (protrusion of radicle by $2 \mathrm{~mm}$ ) was recorded at daily intervals over the course of the 21 days (Ghassemi-Golezani et al., 2008). The seed germination rate was computed using the formula:

\section{$\sum n / \sum D . n$ (Ellis and Roberts, 1980),}

where $n$ is the number of seeds germinated on day $D$, and $D$ is the number of days counted from the beginning of the test.

For further analyses, 21-day-old seedlings were cut from the cotyledon level, and the leaved stem and root were dried at $75 \pm$ $1{ }^{\circ} \mathrm{C}$ for 24 hours in the etuve (Ghassemi-Golezani et al., 2008).

\section{Pot experiments}

Pot experiments were arranged according to a completely randomized design with four replications. Ten seeds from each of the priming treatments were sown at a depth of $3-4 \mathrm{~cm}$ in plastic pots. Each pot had a volume of $1,500 \mathrm{~mL}$ and contained $1,200 \mathrm{~mL}$ of soil mixture comprised of $1 / 3$ sand, $1 / 3$ peat and $1 / 3$ field soil. Water retention capacity was determined before sowing for the 1,200 $\mathrm{mL}$ soil mixture. Pots were irrigated once weekly until the soil reached $50 \%$ of its water-holding capacity. Germination rate (1/day) and percentage (\%) were computed daily by counting all individual seedlings during the 21 days after germination started. The onset of the flowering stage, plant height $(\mathrm{cm})$, number of nitrogen fixed root-nodules, shoot dry weight and root dry weight $(\mathrm{g})$ were determined on five of ten plants in each pot.

\section{Field experiments}

Field experiments were arranged according to a randomized complete block design with three replications. Each plot consisted of 4 rows, each of $3 \mathrm{~m}$ long with $20 \mathrm{~cm}$ row spacing and 180 seeds planted per row. The seeds were planted in wet soil, and germinated seedlings were counted in each $2 \mathrm{~m}$ middle section of the two middle rows of each plot to determine seedling numbers per square meter.

Using ten randomly selected plants, plant height $(\mathrm{cm})$, biological yield (g/plant), number of branches per plant, number of pods per plant, weight of pods per plant $(\mathrm{g})$, number of seeds per plant, grain yield per plant (g/plant) and 1,000 grain weight (g) were measured. The middle two rows of each plot were handharvested to detect grain yield $(\mathrm{kg} / \mathrm{ha})$.

\section{Results}

Electrical conductivity, $\mathrm{pH}$ and seed weight gain (\%) after priming treatments are listed in Table 1.

The results of the analysis of variance (ANOVA) for some plant characteristics in laboratory, pot and field conditions for seed priming effects on lentil seeds are included in Table 2 . There were significant differences among the different priming treatments for all germination traits under laboratory conditions. The effects of seed priming on plant traits observed in pot conditions were significant, with the exception of root length (Table 2). There were significant differences in the agromorphological plant characteristics among seed priming treatments, with the exception of plant height, in the field experiments.

\section{Laboratory experiment}

There were significant differences among seed priming treatments with respect to shoot length, length of seedling root, number of seedling roots, shoot dry weight, root dry weight and germination rate and percentage (Table 3). The lowest shoot and seedling root lengths were observed in seeds treatment with IBA (3.35 and $2.23 \mathrm{~cm}$, respectively), while the greatest shoot length was observed in seeds that received the $\mathrm{GA}_{3}$ treatment $(6.71 \mathrm{~cm})$. $\mathrm{GA}_{3}$ treatment increased the shoot length with $34.2 \%$ when compared to the control.

The control, distilled water and PEG-6000 increased seedling root length, while IBA treatment decreased root length (Table 3). The lowest seedling root number was obtained by treating seeds with $\mathrm{GA}_{3}$ and $\mathrm{KH}_{2} \mathrm{PO}_{4}$ (1.39 and 1.60, respectively). The control, distilled water and PEG-6000 
Table 1. Electrical conductivity and $\mathrm{pH}$ value of priming media and weight increase of primed seeds

\begin{tabular}{|c|c|c|c|c|c|}
\hline \multirow[b]{2}{*}{ Priming media } & \multicolumn{2}{|c|}{ Before seed immersion } & \multicolumn{3}{|c|}{ After seed immersion } \\
\hline & $\begin{array}{l}\text { Electrical conductivity } \\
(\mu \mathrm{S} / \mathrm{cm} / \mathrm{g})\end{array}$ & $\mathrm{pH}$ & $\begin{array}{l}\text { Electrical conductivity } \\
(\mu \mathrm{S} / \mathrm{cm} / \mathrm{g})\end{array}$ & $\mathrm{pH}$ & $\begin{array}{l}\text { Weight increase of } \\
\text { primed seeds (\%) }\end{array}$ \\
\hline $\mathrm{KNO}_{3}(1 \%)$ & 14.05 & 8.0 & 14.01 & 5.6 & 78.2 \\
\hline $\operatorname{KCl}(2 \%)$ & 39.40 & 6.6 & 39.10 & 6.0 & 72.6 \\
\hline $\mathrm{KH}_{2} \mathrm{PO}_{4}(1 \%)$ & 7.41 & 4.8 & 7.40 & 5.4 & 72.3 \\
\hline $\mathrm{ZnSO}_{4}(0.05 \%)$ & 460.00 & 6.2 & 490.00 & 5.5 & 78.2 \\
\hline PEG-6000 (20\%) & 86.00 & 6.6 & 96.60 & 6.6 & 47.7 \\
\hline IBA (100 ppm) & 18.72 & 4.8 & 38.50 & 4.9 & 77.0 \\
\hline Mannitol (4\%) & 1.27 & 8.0 & 29.25 & 7.0 & 73.3 \\
\hline $\mathrm{GA}_{3}(100 \mathrm{ppm})$ & 59.30 & 4.6 & 65.00 & 4.8 & 79.1 \\
\hline Distilled water & 1.50 & 7.8 & 45.80 & 6.6 & 79.8 \\
\hline
\end{tabular}

Table 2. Analysis of variance (ANOVA) for seed priming effects on lentil seed germination and plant characteristics in laboratory, pot and field conditions

\begin{tabular}{|c|c|c|c|c|c|}
\hline \multicolumn{2}{|c|}{ Laboratory observations } & \multicolumn{2}{|c|}{ Pot observations } & \multicolumn{2}{|c|}{ Field observations } \\
\hline Plant characteristics & Mean square & Plant characteristics & Mean square & Plant characteristics & Mean square \\
\hline Shoot length & $4.24090^{* *}$ & Plant height & $33.95^{* *}$ & Number of plants per square & $860.613^{* *}$ \\
\hline Seedling root length & $8.03144^{* *}$ & Root length & 10.93 & Plant height & 12.2877 \\
\hline Number of seedling roots & $3.35770^{* *}$ & Number of root nodules & $31.28^{* *}$ & Biological yield & $0.539404^{* *}$ \\
\hline Shoot dry weight & $0.0000029^{* *}$ & Shoot dry weight & $0.0060^{*}$ & Number of branches per plant & $35.8942^{* *}$ \\
\hline Root dry weight & $0.0000034^{* *}$ & Root dry weight & $0.0012^{* *}$ & Number of pods per plant & $78.1829^{* *}$ \\
\hline Rate of germination & $0.005744^{* *}$ & Germination rate & $0.0052^{* *}$ & Weight of pods per plant & $0.100112^{* *}$ \\
\hline \multirow[t]{4}{*}{ Germination percentage } & $51.1288^{* *}$ & Germination percentage & $1389.17^{* *}$ & Number of seeds per plant & $102.832^{* *}$ \\
\hline & & & & Grain yield per plant & $516.902^{* *}$ \\
\hline & & & & Thousand kernel weight & $102.832^{* *}$ \\
\hline & & & & Grain yield & $516.902^{* *}$ \\
\hline
\end{tabular}

Table 3. Seed priming effects on some germination and seedling properties in laboratory conditions

\begin{tabular}{|c|c|c|c|c|c|c|c|}
\hline $\begin{array}{l}\text { Priming } \\
\text { media }\end{array}$ & $\begin{array}{l}\text { Shoot length } \\
(\mathrm{cm})\end{array}$ & $\begin{array}{l}\text { Root length } \\
(\mathrm{cm})\end{array}$ & $\begin{array}{c}\text { Number of } \\
\text { seedling root }\end{array}$ & $\begin{array}{c}\text { Shoot dry } \\
\text { weight } \\
(\mathrm{mg})\end{array}$ & $\begin{array}{l}\text { Root dry weight } \\
\text { (mg) }\end{array}$ & $\begin{array}{c}\text { Germination } \\
\text { rate } \\
(1 / \text { day })\end{array}$ & $\begin{array}{c}\text { Germination } \\
\text { percentage } \\
(\%)\end{array}$ \\
\hline $\mathrm{KNO}_{3}$ & 3.58 ef* $^{*}$ & $3.93 \mathrm{~d}$ & $2.33 c$ & $2.90 \mathrm{~d}$ & $2.60 \mathrm{c}$ & $0.161 \mathrm{~d}$ & $92 \mathrm{a}$ \\
\hline $\mathrm{KCl}^{* *}$ & -- & -- & -- & -- & -- & $0.082 \mathrm{~g}$ & $26 c$ \\
\hline $\mathrm{KH}_{2} \mathrm{PO}_{4}$ & $3.87 \mathrm{de}$ & $4.48 \mathrm{~cd}$ & $1.60 \mathrm{~d}$ & $3.80 \mathrm{c}$ & $2.40 \mathrm{c}$ & $0.144 \mathrm{e}^{\circ}$ & $81 \mathrm{~b}$ \\
\hline $\mathrm{ZnSO}_{4}$ & $4.70 \mathrm{bc}$ & $5.10 \mathrm{c}$ & $3.26 \mathrm{~b}$ & $4.30 \mathrm{abc}$ & $4.00 \mathrm{~b}$ & $0.182 \mathrm{abc}$ & $97 \mathrm{a}$ \\
\hline PEG-6000 & $4.59 \mathrm{bc}$ & $6.15 b$ & $3.26 \mathrm{~b}$ & $4.80 \mathrm{a}$ & $4.50 \mathrm{ab}$ & $0.168 \mathrm{~cd}$ & $100 \mathrm{a}$ \\
\hline IBA & $3.35 \mathrm{f}$ & $2.23 \mathrm{e}$ & $3.93 \mathrm{a}$ & $2.30 \mathrm{~d}$ & $3.00 \mathrm{c}$ & $0.099 \mathrm{f}$ & $95 \mathrm{a}$ \\
\hline Mannitol & $3.64 \mathrm{ef}$ & $4.95 \mathrm{c}$ & $2.93 \mathrm{~b}$ & $4.00 \mathrm{bc}$ & $4.00 \mathrm{~b}$ & $0.166 \mathrm{~d}$ & $97 a$ \\
\hline $\mathrm{GA}_{3}$ & $6.71 \mathrm{a}$ & $4.27 \mathrm{~d}$ & $1.39 \mathrm{~d}$ & $4.20 \mathrm{abc}$ & $2.80 \mathrm{c}$ & $0.180 \mathrm{bc}$ & $94 \mathrm{a}$ \\
\hline Distillerd water & $4.36 \mathrm{~cd}$ & $6.30 \mathrm{ab}$ & $2.91 \mathrm{~b}$ & $4.60 \mathrm{ab}$ & $4.50 \mathrm{ab}$ & $0.196 \mathrm{a}$ & $97 \mathrm{a}$ \\
\hline Control & $5.00 \mathrm{~b}$ & $6.86 \mathrm{a}$ & $3.96 \mathrm{a}$ & $4.80 \mathrm{a}$ & $5.00 \mathrm{a}$ & $0.186 \mathrm{ab}$ & $100 \mathrm{a}$ \\
\hline
\end{tabular}

${ }^{*}$ Different letters indicate a significant difference of $\mathrm{p} \leq 0.05$;

${ }^{* *}$ Could not obtain data because of the seedlings killed at an advanced stage of germination

Table 4. Seed priming effects on several plant characteristics in pot experiment conditions

\begin{tabular}{|c|c|c|c|c|c|c|c|}
\hline $\begin{array}{l}\text { Priming } \\
\text { media }\end{array}$ & $\begin{array}{l}\text { Plant height } \\
(\mathrm{cm})\end{array}$ & $\begin{array}{l}\text { Root length } \\
(\mathrm{cm})\end{array}$ & $\begin{array}{c}\text { Number of root } \\
\text { nodules }\end{array}$ & $\begin{array}{c}\text { Shoot dry weight } \\
\text { (mg) }\end{array}$ & $\begin{array}{c}\text { Root dry weight } \\
\text { (mg) }\end{array}$ & $\begin{array}{c}\text { Seedling } \\
\text { emergence rate } \\
\text { (1/day) }\end{array}$ & $\begin{array}{c}\text { Seedling } \\
\text { emergence } \\
\text { percentage }(\%)\end{array}$ \\
\hline $\mathrm{KNO}_{3}$ & $14.15 \mathrm{e}^{*}$ & 21.40 & $6.00 \mathrm{~d}$ & $198 \mathrm{~b}$ & $84 \mathrm{~b}$ & $0.162 \mathrm{bc}$ & $87.5 \mathrm{a}$ \\
\hline $\mathrm{KCl}$ & $17.41 \mathrm{bc}$ & 23.85 & $13.80 \mathrm{a}$ & $319 a$ & $121 \mathrm{a}$ & $0.108 \mathrm{c}$ & $57.5 \mathrm{~b}$ \\
\hline $\mathrm{KH}_{2} \mathrm{PO}_{4}$ & $14.48 \mathrm{de}$ & 24.10 & $8.85 \mathrm{~cd}$ & $209 \mathrm{~b}$ & $79 \mathrm{bc}$ & $0.162 \mathrm{bc}$ & $95.0 \mathrm{a}$ \\
\hline $\mathrm{ZnSO}_{4}$ & $14.94 \mathrm{cde}$ & 21.10 & $7.38 \mathrm{~cd}$ & $199 \mathrm{~b}$ & $64 \mathrm{bc}$ & $0.159 \mathrm{bc}$ & $95.0 \mathrm{a}$ \\
\hline PEG-6000 & $14.68 \mathrm{cde}$ & 22.47 & $6.70 \mathrm{~d}$ & $186 \mathrm{~b}$ & $71 \mathrm{bc}$ & $0.166 \mathrm{~b}$ & $95.0 \mathrm{a}$ \\
\hline IBA & 16.69 bcde & 19.12 & $11.95 \mathrm{ab}$ & $205 \mathrm{~b}$ & $83 \mathrm{bc}$ & $0.123 b c$ & $97.5 \mathrm{a}$ \\
\hline Mannitol & $17.02 \mathrm{bcd}$ & 21.02 & $12.10 \mathrm{ab}$ & $211 b$ & $77 \mathrm{bc}$ & $0.164 \mathrm{bc}$ & $97.5 \mathrm{a}$ \\
\hline $\mathrm{GA}_{3}$ & $23.93 \mathrm{a}$ & 20.92 & $7.70 \mathrm{~cd}$ & $201 \mathrm{~b}$ & $66 \mathrm{bc}$ & $0.236 \mathrm{a}$ & $45.0 \mathrm{~b}$ \\
\hline Distilled water & $17.95 \mathrm{~b}$ & 19.50 & $10.00 \mathrm{bc}$ & $189 \mathrm{~b}$ & $56 c$ & $0.133 b c$ & $92.5 \mathrm{a}$ \\
\hline Control & $18.42 \mathrm{~b}$ & 20.45 & $12.85 \mathrm{ab}$ & $234 \mathrm{~b}$ & $76 \mathrm{bc}$ & $0.120 \mathrm{bc}$ & $95.0 \mathrm{a}$ \\
\hline
\end{tabular}

${ }^{*}$ Different letters indicate a significant difference of $\mathrm{p} \leq 0.05$ 
156

Table 5. Seed priming effects on several plant characteristics in field experiment conditions

\begin{tabular}{|c|c|c|c|c|c|c|c|}
\hline $\begin{array}{l}\text { Priming } \\
\text { media }\end{array}$ & $\begin{array}{l}\text { Number of plants } \\
\text { per square meter }\end{array}$ & $\begin{array}{c}\text { Plant height } \\
(\mathrm{cm})\end{array}$ & $\begin{array}{c}\text { Biological yield } \\
(\mathrm{g} / \text { plant })\end{array}$ & $\begin{array}{c}\text { Number of } \\
\text { pods per plant }\end{array}$ & $\begin{array}{c}\text { Number of } \\
\text { seeds per plant }\end{array}$ & $\begin{array}{l}\text { Grain yield per } \\
\text { plant (g/plant) }\end{array}$ & $\begin{array}{l}1000 \text { grain } \\
\text { weight }(\mathrm{g})\end{array}$ \\
\hline $\mathrm{KNO}_{3}$ & $217.5 \mathrm{~d}^{*}$ & 49.0 & $2.468 \mathrm{a}$ & $11.13 \mathrm{ab}$ & $6.60 \mathrm{~cd}$ & $0.277 \mathrm{~cd}$ & $35.77 \mathrm{~b}$ \\
\hline $\mathrm{KCl}$ & $236.8 \mathrm{bcd}$ & 43.9 & $1.990 \mathrm{c}$ & $15.30 \mathrm{a}$ & $15.05 \mathrm{a}$ & $0.488 \mathrm{ab}$ & $26.09 \mathrm{~cd}$ \\
\hline $\mathrm{KH}_{2} \mathrm{PO}_{4}$ & $266.8 \mathrm{a}$ & 43.8 & $2.046 \mathrm{bc}$ & $3.80 \mathrm{~d}$ & $3.75 \mathrm{de}$ & $0.363 \mathrm{bc}$ & $23.47 \mathrm{~d}$ \\
\hline $\mathrm{ZnSO}_{4}$ & $244.3 \mathrm{abcd}$ & 49.4 & $2.126 \mathrm{bc}$ & $14.55 \mathrm{a}$ & $18.25 \mathrm{a}$ & $0.678 \mathrm{a}$ & $37.17 \mathrm{~b}$ \\
\hline PEG-6000 & $229.5 \mathrm{~cd}$ & 45.3 & $1.452 \mathrm{~d}$ & $9.40 \mathrm{bc}$ & $10.00 \mathrm{~b}$ & $0.376 \mathrm{bc}$ & $37.60 \mathrm{~b}$ \\
\hline IBA & $251.2 \mathrm{abc}$ & 45.4 & $1.452 \mathrm{~d}$ & $11.20 \mathrm{ab}$ & $10.55 \mathrm{~b}$ & $0.388 \mathrm{bc}$ & $35.50 \mathrm{~b}$ \\
\hline Mannitol & $243.3 \mathrm{abcd}$ & 45.8 & $2.031 \mathrm{bc}$ & $8.56 \mathrm{bc}$ & $4.00 \mathrm{de}$ & $0.152 \mathrm{de}$ & $37.45 \mathrm{~b}$ \\
\hline $\mathrm{GA}_{3}$ & $241.04 \mathrm{abcd}$ & 43.8 & $2.226 \mathrm{~b}$ & $8.60 \mathrm{bc}$ & $2.93 \mathrm{e}$ & $0.058 \mathrm{e}$ & $34.87 \mathrm{~b}$ \\
\hline Distilled water & $216.6 \mathrm{~d}$ & 46.9 & $1.333 \mathrm{~d}$ & $6.33 \mathrm{~cd}$ & $4.93 \mathrm{de}$ & $0.133 \mathrm{de}$ & $29.47 c$ \\
\hline Control & $263.3 \mathrm{ab}$ & 46.6 & $2.542 \mathrm{a}$ & $10.10 \mathrm{bc}$ & $8.30 \mathrm{bc}$ & $0.353 \mathrm{bc}$ & $42.57 \mathrm{a}$ \\
\hline
\end{tabular}

${ }^{*}$ Different letters indicate a significant difference of $\mathrm{p} \leq 0.05$

treatments significantly increased root dry weight when compared to the other priming treatments. IBA and $\mathrm{KNO}_{3}$ treatments decreased shoot dry weight, while $\mathrm{GA}_{3}, \mathrm{KH}_{2} \mathrm{PO}_{4}$ and $\mathrm{KNO}_{3}$ treatments decreased root dry weight. The lowest germination rate was observed in seeds treated with $\mathrm{KCl}$ and IBA (0.082 and 0.099 1/day, respectively), while the highest germination rate was observed in seeds treated with distilled water $(0.1961 /$ day $)$. All control seeds and those treated with PEG-6000 germinated (100\%) (Table 3).

\section{Pot experiment}

There were significant differences for all plant characteristics, with the exception of root length, among different priming treatments in the pot experiment (Table 4).

Of all the seed priming treatments used, the $\mathrm{GA}_{3}$ treatment significantly improved plant height, which increased $40 \%$ over the control and $30 \%$ over seeds primed with distilled water in pot conditions (Table 4). $\mathrm{KCl}$ treatment improved the number of nodules, as well as root and shoot dry weight. $\mathrm{GA}_{3}$ seed priming treatment increased the seedling emergence rate $(0.2361 /$ day $)$ when compared to the control and other priming treatments, while $\mathrm{KCl}$ treatment caused a decrease in the seedling emergence rate. $\mathrm{GA}_{3}$ and $\mathrm{KCl}$ priming treatments decreased the seedling emergence percentage when compared to the control (Table 4).

\section{Field experiment}

There were significant differences among priming media for all the plant characteristics observed in field conditions, with the exception of plant height (Table 5). The greatest number of plants per square meter was detected in plants grown from seeds treated with $\mathrm{KH}_{2} \mathrm{PO}_{4}$ (266.8), while the lowest number of plants was observed in plants grown from seeds that had undergone the distilled water treatment (216.6). The highest biological yields recorded were in the control group and the group that had received $\mathrm{KNO}_{3}$ treatment (2.562 and $2.468 \mathrm{~g}$, respectively), while the lowest biological yield was observed in the group that received the distilled water treatment $(1.333 \mathrm{~g})$. The number of pods per plant ranged between $3.80-15.30$. $\mathrm{KCl}$ and $\mathrm{ZnSO}_{4}$ treatments increased the number of pods per plant when compared to the control. Likewise, the number of seeds per plant increased when seeds were treated with $\mathrm{ZnSO}_{4}$ and $\mathrm{KCl}$ (18.25 and 15.05 , respectively), while the lowest number of seeds per plant was observed in the group treated with $\mathrm{GA}_{3}(2.93$ seeds/plant). Grain yield per plant ranged between 0.058 and $0.678 \mathrm{~g}\left(\mathrm{GA}_{3}\right.$ and $\mathrm{ZnSO}_{4}$, respectively). The greatest 1,000 grain weight was obtained by the control group ( $42.57 \mathrm{~g})$, while the lowest was detected in those treated with $\mathrm{KH}_{2} \mathrm{PO}_{4}$ (Table 5).

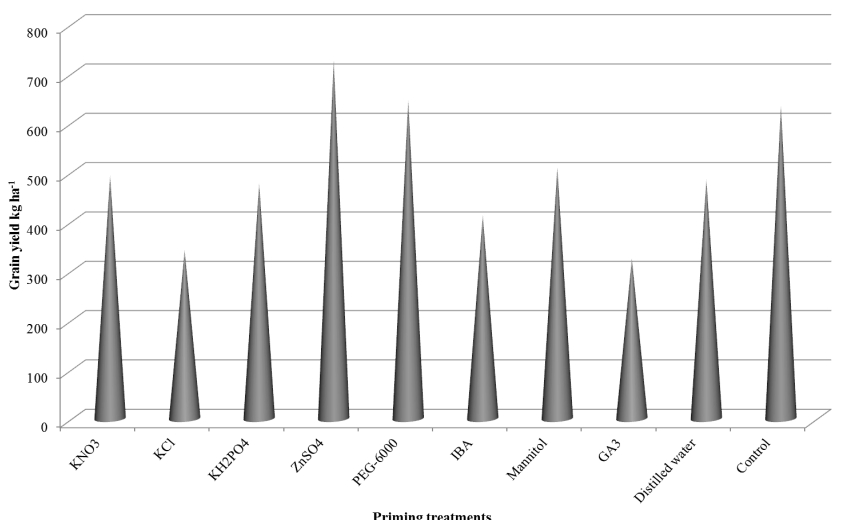

Fig. 1. Comparison of means for seed priming effects on lentil for grain yield

Grain yield results showed that treating seeds with $\mathrm{ZnSO}_{4}$ and PEG-6000 improved the grain yield compared to control (Fig. 1). So, partially increase in grain yield by the treatment of some priming agents $\left(\mathrm{ZnSO}_{4}\right.$ and PEG-6000) should be considered detailed with more investigations. Significant decreases in grain yield were observed in the $\mathrm{GA}_{3}$ and $\mathrm{KCl}$ treatments when compared to the control.

\section{Discussions}

$\mathrm{KCl}$ salts negatively affected the germination properties of lentil seeds in both laboratory and pot conditions. The reason for the decreased germination percentage may be explained by the toxic effect of $\mathrm{KCl}$ salts on germinating embryos, which caused the decreased germination percentage and deaths of the seedlings. Similar effects of $\mathrm{KCl}$ treatment on wheat seeds have been reported by Giri and Schillinger (2003) and Yari et al. (2011). In this research, $\mathrm{GA}_{3}$ treatment of lentil seeds caused an increase in plant height in both laboratory and pot conditions. Considering $\mathrm{GA}_{3}$ is a plant growth hormone, its effect on promoting growth is slight. In addition, positive effects of $\mathrm{GA}_{3}$ treatment were observed on the germination and seedling emergence rates (Tables 3 and 4). Positive effects of $\mathrm{GA}_{3}$ treatment effects reported include breaking seed dormancy, promoting germination, increasing inter-node length, increasing plant height and encouraging cell division (Ghodrat and Rousta, 2012; Naeem and Muhammad, 2006; Rood et al., 1990). In environments marked by dry or inadequate humidity at seedbed, $\mathrm{GA}_{3}$ treatment may provide an advantage due to the increase germination rate. Iqbal and Ashraf (2013) reported that $\mathrm{GA}_{3}$ treatment to wheat seeds increased grain yield and resistance to salt stress. 
A greater number of nodules, along with increased root and shoot dry weight, following treatment of seeds with $\mathrm{KCl}$ may be explained by the low number of germinated seeds, but those that did germinate showed better development of root and shoot. The results of the laboratory and pot experiments showed that the IBA treatment decreased root length, while increasing the number and weight of roots. Decastro et al. (2000) reported that IAA, IBA and NAA seed treatments enhanced root formation and development. The positive effect of $\mathrm{ZnSO}_{4}$ treatment on the number of seeds and number of pods per plant and grain yield may be explained by the homogenizing effect of $\mathrm{ZnSO}_{4}$ on soil minerals at the root zone of plants and by its ability to facilitate nutrient uptake by plants. In addition, the higher anthracnose incidence that occurred during the growing season revealed that $\mathrm{ZnSO}_{4}$ treated plants exhibit greater resistance to the disease, which resulted in a slightly higher grain yield among seeds treated with $\mathrm{ZnSO}_{4}$ when compared to the control and seeds that underwent other priming treatments. However, more research is needed on this topic. These results are in agreement with results reported in Kaya et al. (2007), which demonstrated that $\mathrm{Zn}$ priming treatment on phaseolus seeds increased grain yield and yield components; Ajouri et al. (2004) also reported that $\mathrm{Zn}$ treatment to barley seeds increased germination and seedling development; and Marschner (1995) reported that higher Zn content of seeds at the germination stage increased resistance to soil-borne diseases.

\section{Conclusions}

As result of this study, it could be concluded that, with respect to germination properties, several plant characteristics, grain yield components and grain yield, $\mathrm{GA}_{3}, \mathrm{PEG}$ and $\mathrm{ZnSO}_{4}$ priming treatments should be considered, and further research is needed in order to obtain more conclusive results.

\section{References}

Ali MO, Sarkar A., Rahman MM, Gahoonia TS, Uddin MK (2005). Improvement of lentil yield through seed priming in Bangladesh. Journal of Lentil Research 2:54-59.

Ajouri A, Asgedom H, Becker M (2004). Seed priming enhances germination and seedling growth of barley under conditions of $P$ and Zn deficiency. J Plant Nutr Soil Sc 167:630-636.

Ashraf M, Rauf H (2001). Inducing salt tolerance in maize (Zea mays L.) through seed priming with chloride salts: Growth and ion transport at early growth stages. Acta Physio Plant 23:407-414

Ashraf M, Foolad MR (2005). Pre-sowing seed treatment: A shotgun approach to improve germination, plant growth and crop yield under saline and non-saline conditions. Adv Agron 88:223-271.

Basra SMA, Farooq M, Khaliq A (2003). Comparative study of pre-sowing seed enhancement treatments in indica rice (Oryza sativa L.). Pakistan Journal of Life and Social Science 1:5-9.

Bradford KJ (1986). Manipulation of seed water relations via osmotic priming to improve germination under stress conditions. Hortic Sci 21:1105-1112.
Cheng Z, Bradford KJ (1999). Hydrothermal time analysis of tomato seed germination responses to priming treatments. J Exp Bot 33:89-99.

Cubero JI (1981). Origin, taxonomy and domestication. In: Lentils. Webb C, Havtin G (Eds), CAB, London, UK pp 1538.

De Castro RD, van Lammeren AA, Groot SP, Bino RJ, Hilhorst HW (2000). Cell division and subsequent radicle protrusion in tomato seeds are inhibited by osmotic stress but DNA synthesis and formation of microtubular cytoskeleton are not. Plant Physiol 122:327-336.

Ellis RH, Roberts EH (1980). Towards rational basis for testing seed quality. Hebblethwaite, PD (Ed), Seed Production, Butterworths, London pp 605-635.

FAO 2013. Statistical database. Available from: URL: http://www.fao.org.

Fischer RA, Turner NC (1978). Plant productivity in the arid and semiarid zones. Ann Rev Plant Physio 29:277-317.

Ghasemi-Golezani K, Aliloo AA, Valizadeh M, Moghaddam M (2008). Effects of different priming techniques on seed invigoration and seedling establishment of lentil (Lens culinaris Medik.). J Food Agric Environ 6:222-226.

Ghasemi-Golezani K, Japparpour-Bonyadi Z, Shafagh-Kolvanagh J, Nikpour-Rashidabad N (2013). Effects of water stress and hydro-priming duration on field performance of lentil. International Journal of Farming and Allied Sciences 2:922925.

Ghodrat V, Rousta MJ (2012). Effect of priming with gibberellic acid $\left(\mathrm{GA}_{3}\right)$ on germination and growth of corn (Zea mays L.) under saline conditions. Int J Agri Crop Sci 4:883-885.

Giri GS, Schillinger WF (2003). Seed priming winter wheat for germination, emergence and yield. Crop Sci 43:2135-2141.

Iqbal M, Ashraf M (2013). Gibberellic acid mediated induction of salt tolerance in wheat plants: Growth, ionic partitioning, photosynthesis, yield and hormonal homeostasis. Environ Exp Bot 86:76-85.

Karakoy T, Erdem H, Baloch FS, Toklu F, Eker S, Kilian B, Özkan H (2012). Diversity of macro- and micronutrients in the seeds of lentil landraces. The Scientific World Journal doi:10.1100/2012/710412.

Kaya M, Atak M, Khawar KM, Ciftci CY, Ozcan S (2007). Effect of pre-sowing seed treatment with zinc and foliar spray of humic acids on yield of common bean (Phaseolus vulgaris L.). Int J Agr Biol 7:875-878.

Khan AA (1992). Preplant physiological seed conditioning. Hortic Rev 13:131-181.

Lev-Yadun S, Gopher A, Abbo S (2000). The cradle of agriculture. Science 288:1602-1603.

Marschner H (1995). Mineral nutrition of higher plants, $2^{\text {nd }}$ ed. San Diego: Academic Press.

McDonald MB (2000). Seed priming. In: Seed technology and its biological basis. Black, M, Bewley JD (Eds), Sheffield Academic Press, Sheffield, UK pp 287-325. 
158

Michel BE, Kaufmann MR (1973). The osmotic potential of polyethylene glycol 6000. Plant Physiol 51:914-916.

Muehlbauer FJ, Cho S, Sarker A, McPhee KE, Coyne CJ, Rajesh PN, Ford R (2006). Application of biotechnology in breeding lentil for resistance to biotic and abiotic stress. Euphytica 147:149-165.

Naeem MA, Muhammad S (2006). Effect of seed priming on growth of barley (Hordeum vulgare) by using brackish water in salt affected soils. Pakistan J Bot 38:613-622.

Parera CA, Cantliffe DJ (1994). Pre-sowing seed priming. Hortic Rev 16:109-141.

Rood SB, Buzzell RI, Major DJ, Pharis RP (1990). Gibberellins and heterosis in maize: quantitative relationship. Crop Sci 30:281-286.

Saglam S, Dayi S, Kaya G, Gurbuz A (2010). Hydropriming increases germination of Lentil (Lens culinaris Medik.) under water stress. Not Sci Biol 2:103-106.
Solanki IS, Kapoor AC, Singh U (1999). Nutritional parameters and yield evaluation of newly developed genotypes of lentil (Lens culinaris Medik.). Plant Food Hum Nutr 54:79-87.

Subedi KD, Ma BL (2005). Seed priming does not improve corn yield in a humid temperate environment. Agron J 97:211-218.

Taylor AG, Allen PS, Bennett MA, Bradford KJ, Burris JS, Misra MK (1998). Seed enhancements. Seed Sci Res 8:245-256.

Yordanov I, Velikova V, Tsonev T (2000). Plant responses to drought, acclimation and stress tolerance. Photosynthetica 38:171-186.

Yari L, Khazaei F, Sadeghi H, Sheidaei S (2011). Effect of seed priming on grain yield and yield components of bread wheat (Triticum aestivum L.). J Agr Biol Sci 6:1-5. 